Scientific Review - Engineering and Environmental Sciences (2019), 28 (3), 417-431

Sci. Rev. Eng. Env. Sci. (2019), 28 (3)

Przegląd Naukowy - Inżynieria i Kształtowanie Środowiska (2019), 28 (3), 417-431

Prz. Nauk. Inż. Kszt. Środ. (2019), 28 (3)

http://iks.pn.sggw.pl

DOI 10.22630/PNIKS.2019.28.3.39

\author{
Ali Jaafar DAKHIL ${ }^{1}$, Saba Mohammad SHAHEED ${ }^{1}$, Dheyaa A. ALOBAIDI ${ }^{2}$ \\ ${ }^{1}$ Collage of Engineering, University of Al-Qadisiyah \\ ${ }^{2}$ Iraqi Ministry of Education
}

\title{
Studying and evaluating the performance of pedestrian crossing facilities in Babil governorate
}

Key words: pedestrian, traffic, interview survey, bridge

\section{Introduction}

A study of pedestrian traffic and their environment conducted in the city of Manhattan and traffic volumes were an estimate and their movement in aerial photography as well as the use of mechanical and electronic meters and the study. To study the relationship between different land uses and pedestrian movement and traffic volumes. These relationships are described in order to analyze the future relationship and prediction of the environmental movement so that the results show that. Will be an essential tool to assist planners and decision-makers in identifying and providing scalable pathways to accommodate expansion. As well as the various environmental, social and urban factors that would provide safety and safety of the port while traveling and the need for pedestrian crossing facilities in the study area (Batty et al., 2012)

In the United States, primary school students' trips were studied as a large proportion of walking trips are often made up of small age groups with limited ability to estimate the speed of the next vehicle as they travel through their journey to and from school (AASHTO, 2001). The amount of safety in the trip is calculated by assigning the number of hazardous areas and junctions the student travels. The results indicated that approximately $28 \%$ of children do not experience a risk during the trip and that the location of the school has an impact on child mobility (Iraqi Ministry of Highway and Construction, 1982; Iraqi Ministry of Interior, 1984; Garber \& Hoel, 2002). British company Scott Wilson (Iraqi Ministry of Interior, 1984) studied the comprehensive transport of the city of Baghdad, which included the study (traffic volumes, public transport, noise pollution and air, visual distortion, 
etc.). This study was limited to the development of temporary solutions for pedestrian movement through transit areas, traffic signs, etc., and did not address the characteristics of pedestrians, their environment, traffic routes and the relationship of pedestrian traffic to the various land uses.

That the fundamental problem dealt with by the research is the random crossing of the pedestrian and non-controlled and this is what has be done monitoring in the study area as well as the lack of safe access to the city where this study attempts to analyze and sidewalk (Iraqi Ministry of Highway and Construction, 1982; Iraqi Ministry of Interior, 1984; Brand, 2010).

The current traffic condition of these walks as well as the state of bridges to cross the pedestrian and then solutions and treatments needed to reduce or limit level of cases of interference between different traffic events and cross-crossing events and thus raise the level of service for the city's road and bridge network and no slowdown of the service-load to the irregular crossing of the pedestrian.

This research is necessary because it is one of the few research that tries to highlight a problem of pedestrians as most studies are concerned with addressing.

The problems of volumes and traffic jams while being neglected to a certain extent great handling of pedestrian traffic and their movements that would lead to traffic-type traffic accidents (F) and F (Fatal), which causes deaths (vehicle-pedestrian). Most of the designs for the road network (P.I.) are also mark by personal injuries or disabilities the city did not address this critical problem, so the study decided to go into this field and try to develop solutions and its treatments (Owira, 2009).

\section{Material and methods}

\section{Description of the study area}

Traffic counting stations have been elect to achieve diversity in different land uses (Fig. 1), in order for the data to be derived from reflecting the reality of the sample to be studied. Thus, educational zones (secondary, university), commercial and residential were studied.

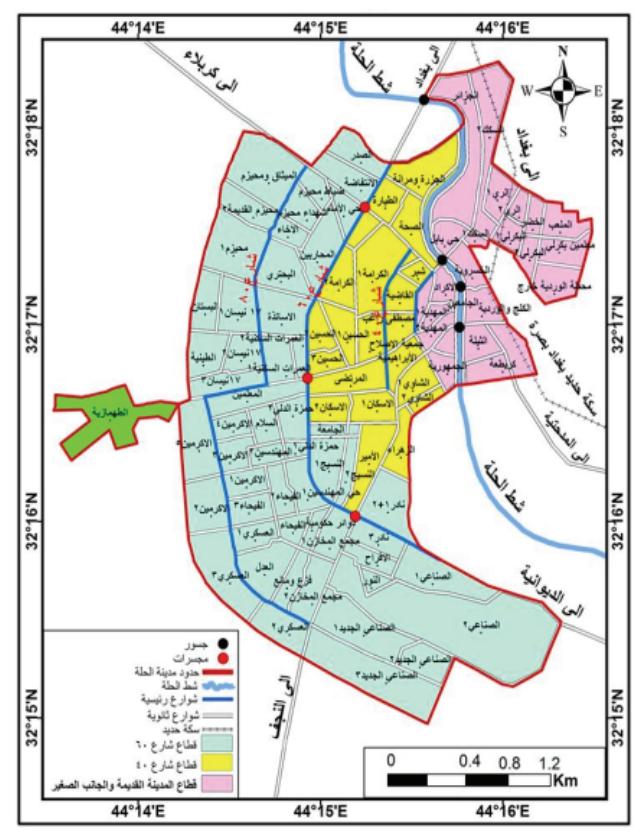

FIGURE 1. The master plan for the city of Hilla, indicating the traffic counting stations

Babel District - the intersection of the Babel Health Department - traffic count station No 1 . An area where educational and service activities are concentrated, as most pedestrians use the 
road. Where they are secondary school students with a different level of education. This area is characterized by two-way traffic separated by an intermediate carrot and the road is equipped with sidewalks in both directions (Fig. 2).

Area of Al-Hussein - Al-Fayha bridge - traffic count station No 2 . The city's commercial and business center (central business district - CBD) and the city's internal transport depot have made it a center of attraction for pedestrian traffic, traffic and transport (Fig. 3).

Area of $60^{\text {th }}$ Street, pedestrian crossing bridge near the Academy of Fine Arts - traffic count station No 3. This is a university education area and a government and residential services area. As there is an outdoor transport facility for travelers in this area, many pedestrian movements and activities use the area to reach different ends. The study monitored pedestrian movements on the bridge and ground movements to analyze and evaluate pedestrian crossing in these area (Fig. 4).

Area of $40^{\text {th }}$ Street, near the Department of Awqaf - traffic count station No 4. This area is located near the Department of Endowments in Babylon, and this area is characterized by diversity of land uses (residential, commercial, religious), pedestrian movements are carried out through shopping or reaching other ends and destinations. The road in this area has a two-way pass and is separated by an intermediate and

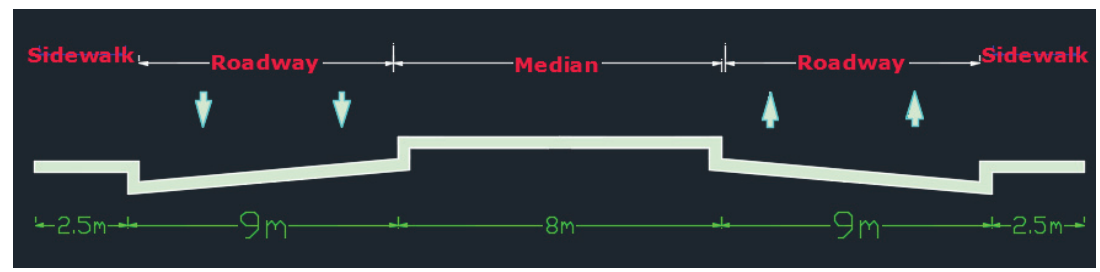

FIGURE 2.The road section of traffic station No 1

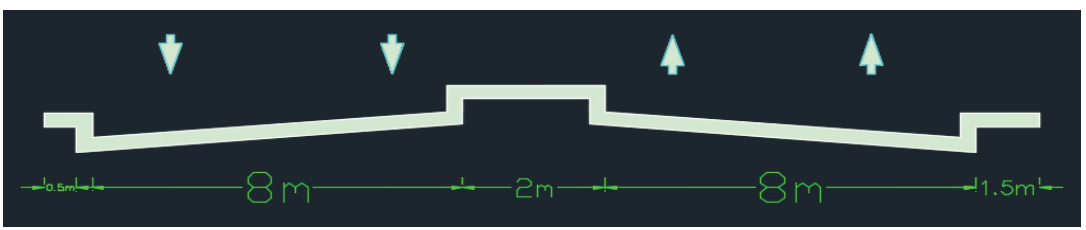

FIGURE 3.The road section of the traffic station No 2

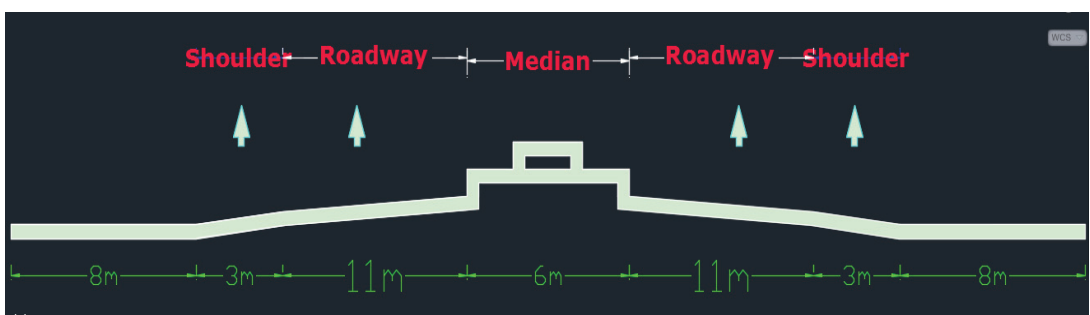

FIGURE 4.The road section of the traffic station No 3 
side-by-side carrot. The diversity of the above-mentioned land uses increased pedestrian traffic volumes, which necessitates studying this area (Fig. 5).
The field information on pedestrian traffic volumes, speed, and capacity of roadways, bridges and traffic volumes of vehicles have been collected and classi-

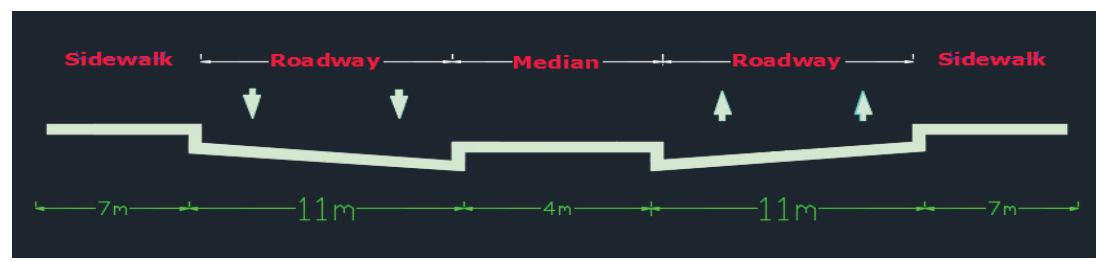

FIGURE 5. The road section of the traffic station No 4

\section{Collection of field information}

Field traffic flow data were collected in units (number of vehicles per hour $\left.v e h . h^{-1}\right)$. The calculation of traffic volumes was calculated every quarter of an hour from the critical hour (rate of flow) and the critical hour is determined by the condition of the road and over a week on 1-7 March 2018.

The minimum size of the required sample was represented by the following equation:

$N_{\text {min }}=\frac{S \cdot \mathrm{K}}{\mathrm{E}} \cdot 2$

whereas:

$N_{\min }-$ the smallest size for sample;

$S$ - number of views;

$\mathrm{K}$ - constant equal 1.96 to $95 \%$ confidence level;

$\mathrm{E}$ - permissible error equal 2.

When calculating the smallest size of the sample required for the speed of passage in the study area and on the basis of deviation standard: $12 \mathrm{r} \cdot \mathrm{km}^{-1}, \mathrm{~K}=1.96$ and $\mathrm{E}=2$. Therefore, the smallest size of the sample shall be $N=\left(10 \cdot \frac{1.96}{2}\right)^{2}=96.04$. fied in two phases: survey and measurements at the station.

In the survey phase, an inquiry was carried out covering the study area to determine the concentration of infantry activities the condition of the bridges for their passage and the condition of the sidewalks and the extent of need. The survey also included traffic peak hours, traffic density and the concentration of pedestrian crossing activities and the location of counting stations and traffic statistics.

In station installation and measurement phase, the counting and traffic count stations and the field data collection mentioned above were installed using the photograph technique method, which is an efficient and reliable method for calculating the necessary data for pedestrians and vehicles or the calculation of the time of crossing the pedestrian crossing bridges or the road, where the traffic peak hour was filmed by experiencing the status of counting stations survey for a week on 1-7 March 2018 and the peak hour for a pedestrian crossing (pedestrian peak hour) as shown in Table 1. 
TABLE 1. Shows the peak hour of the traffic count stations

\begin{tabular}{|c|c|c|}
\hline $\begin{array}{c}\text { Traffic } \\
\text { count } \\
\text { station }\end{array}$ & $\begin{array}{c}\text { Rush } \\
\text { hour }\end{array}$ & $\begin{array}{c}\text { Day } \\
\text { of a week }\end{array}$ \\
\hline 1 & $7: 00-8: 00$ & Sunday \\
\hline 2 & $7: 30-8: 30$ & Sunday \\
\hline 3 & $7: 45-8: 45$ & Monday \\
\hline 4 & $7: 30-8: 30$ & Thursday \\
\hline
\end{tabular}

\section{Results and dissociation}

The study began analyzing field data collected from traffic counting stations in the study area. The study selected random samples of pedestrian samples representing different age groups as well as different cultural and social levels to monitor their movements at land crossings or using bridges. Tables 2, 4, 6, and 9 illustrate the time taken for crossing pedestrians using the road. The tables show that the first and second waiting time is very high for four traffic count stations and this is what presents pedestrians to the sudden and random descent of the road, thus exposing pedestrians to the risk of crossing, as well as increasing the delay time for their trips.

Table 8 shows the time taken to cross the pedestrian crossing by using the bridge to station No 3 . Tables $3,5,7$ and 10 show the pedestrian traffic volumes in the study area (Brand, 2010) for the $60^{\text {th }}$ Street area near the Academy of Fine Arts, the study noted that the number of pedestrians used for the pedestrian crossing bridge increasing the number of pedestrians used for land crossing. The study attempted to find out the causes of this problem. A questionnaire was designed for this purpose. As shown in Table 11, different segments of the ages and cultural levels were polled. The reasons in the land passage while

TABLE 2. The time taken for the pedestrian crossing using the road to the traffic count station No 1, the intersection of Babel Health Department

\begin{tabular}{|c|c|c|c|c|c|}
\hline No & $\begin{array}{c}\text { Standby time } \\
\text { before transit } \\
{[\mathrm{s}]}\end{array}$ & $\begin{array}{c}\text { Time } \\
\text { of crossing street } \\
{[\mathrm{s}]}\end{array}$ & $\begin{array}{c}\text { Time to walk } \\
\text { on the middle } \\
\text { carrot } \\
{[\mathrm{s}]}\end{array}$ & $\begin{array}{c}\text { Wait time } \\
\text { on the carrot } \\
{[\mathrm{s}]}\end{array}$ & $\begin{array}{c}\text { Transit time } \\
\text { of the other } \\
\text { direction } \\
{[\mathrm{s}]}\end{array}$ \\
\hline 1 & 5.1 & 16.6 & 7.16 & 8 & 20.73 \\
\hline 2 & 3 & 15.1 & 5.1 & 9 & 21.7 \\
\hline 3 & 2 & 14 & 5.1 & 9 & 21.2 \\
\hline 4 & 2 & 13.9 & 5 & 9.6 & 21.1 \\
\hline 5 & 3 & 15 & 5 & 8.2 & 21.2 \\
\hline 6 & 4 & 16 & 6.6 & 7 & 21 \\
\hline 7 & 1.5 & 16 & 6 & 7 & 21.7 \\
\hline 8 & 2 & 15 & 6 & 7 & 21.1 \\
\hline 9 & 2 & 14.44 & 5 & 7.7 & 20.33 \\
\hline 10 & 5 & 15 & 7 & 8 & 18 \\
\hline 11 & 5 & 16.03 & 8 & 8 & 18 \\
\hline 12 & 3 & 16 & 7 & 7 & 18.9 \\
\hline
\end{tabular}


TABLE 2 cont.

\begin{tabular}{|c|c|c|c|c|c|}
\hline No & $\begin{array}{c}\text { Standby time } \\
\text { before transit } \\
{[\mathrm{s}]}\end{array}$ & $\begin{array}{c}\text { Time } \\
\text { of crossing street } \\
{[\mathrm{s}]}\end{array}$ & $\begin{array}{c}\text { Time to walk } \\
\text { on the middle } \\
\text { carrot } \\
{[\mathrm{s}]}\end{array}$ & $\begin{array}{c}\text { Wait time } \\
\text { on the carrot } \\
{[\mathrm{s}]}\end{array}$ & $\begin{array}{l}\text { Transit time } \\
\text { of the other } \\
\text { direction } \\
{[\mathrm{s}]}\end{array}$ \\
\hline 13 & 6 & 14 & 7 & 7.1 & 17 \\
\hline 14 & 4 & 13 & 9 & 8 & 15 \\
\hline 15 & 2 & 12.22 & 7.2 & 9 & 15.2 \\
\hline 16 & 2 & 15 & 4.9 & 9 & 18.8 \\
\hline 17 & 1 & 15 & 5 & 11 & 19 \\
\hline 18 & 3 & 14 & 5 & 9 & 19.1 \\
\hline 19 & 1 & 13 & 5 & 9 & 19.22 \\
\hline 20 & 4 & 11.11 & 6 & 8 & 19 \\
\hline 21 & 6 & 14 & 7 & 7 & 21 \\
\hline 22 & 3 & 14 & 7 & 6 & 21 \\
\hline 23 & 2 & 13 & 7.8 & 7 & 17.66 \\
\hline 24 & 2 & 15 & 7.6 & 6 & 17.61 \\
\hline 25 & 2 & 15 & 7 & 5 & 17 \\
\hline 26 & 2 & 15 & 6 & 7 & 16.9 \\
\hline 27 & 5 & 12 & 5.69 & 7 & 17 \\
\hline 28 & 5 & 13.99 & 5 & 7 & 16.2 \\
\hline 29 & 4 & 14 & 5 & 6 & 16 \\
\hline 30 & 5 & 15 & 5 & 5 & 16 \\
\hline
\end{tabular}

TABLE 3. The traffic size of the pedestrian on the traffic count station No 1 - the intersection of Babel Health Department at the traffic peak hour

\begin{tabular}{|c|c|c|c|}
\hline \multicolumn{2}{|c|}{ Orientation: Secondary Distinguished Girls } & \multicolumn{2}{|c|}{ Orientation: Preparatory Hilla Girls } \\
\hline $\begin{array}{c}\text { Traffic volume } \\
\text { of pedestrians }\end{array}$ & $\begin{array}{c}\text { Time } \\
{[\mathrm{min}]}\end{array}$ & $\begin{array}{c}\text { Traffic volume } \\
\text { of pedestrians }\end{array}$ & $\begin{array}{c}\text { Time } \\
{[\mathrm{min}]}\end{array}$ \\
\hline 23 & $0-5$ & 43 & $0-5$ \\
\hline 37 & $5-10$ & 69 & $5-10$ \\
\hline 39 & $10-15$ & 77 & $10-15$ \\
\hline 45 & $15-20$ & 88 & $15-20$ \\
\hline 45 & $20-25$ & 92 & $20-25$ \\
\hline 49 & $25-30$ & 90 & $25-30$ \\
\hline 52 & $30-35$ & 72 & $30-35$ \\
\hline 57 & $35-40$ & 73 & $35-40$ \\
\hline 39 & $40-45$ & 66 & $40-45$ \\
\hline 37 & $45-50$ & 57 & $45-50$ \\
\hline 21 & $50-55$ & 43 & $50-55$ \\
\hline 27 & $55-60$ & 39 & $55-60$ \\
\hline
\end{tabular}


TABLE 4. The time taken for the crossing of pedestrians using the road to the traffic count station No 2 - area of Al-Hussein - Al-Fayha bridge

\begin{tabular}{|c|c|c|c|c|c|}
\hline No & $\begin{array}{c}\text { Standby time } \\
\text { before transit } \\
{[\mathrm{s}]}\end{array}$ & $\begin{array}{c}\text { Time of } \\
\text { crossing street } \\
{[\mathrm{s}]}\end{array}$ & $\begin{array}{c}\text { Time to walk } \\
\text { on the middle } \\
\text { carrot } \\
{[\mathrm{s}]}\end{array}$ & $\begin{array}{c}\text { Wait time } \\
\text { on the carrot } \\
{[\mathrm{s}]}\end{array}$ & $\begin{array}{c}\text { Transit time } \\
\text { of the other } \\
\text { direction } \\
{[\mathrm{s}]}\end{array}$ \\
\hline 1 & 17.67 & 12.24 & 4.41 & 30.19 & 13.28 \\
\hline 2 & 24.40 & 12.51 & 2.23 & 1 & 12.92 \\
\hline 3 & 17.68 & 12.06 & 6.09 & 6.38 & 12.85 \\
\hline 4 & 16.48 & 13.55 & 3.67 & 5.20 & 14 \\
\hline 5 & 13.78 & 11.24 & 5.66 & 4.91 & 14.07 \\
\hline 6 & 28.40 & 11.76 & 3.22 & 2 & 15 \\
\hline 7 & 5 & 13.66 & 3.90 & 13.53 & 12.74 \\
\hline 8 & 7.10 & 10.69 & 2.05 & 2 & 12.25 \\
\hline 9 & 20.07 & 14.31 & 2.01 & 7.60 & 14 \\
\hline 10 & 12.09 & 13.78 & 3.03 & 3 & 14.95 \\
\hline 11 & 7.79 & 16.55 & 2 & 30.63 & 18.34 \\
\hline 12 & 2 & 16.33 & 3.60 & 10.54 & 16.68 \\
\hline 13 & 28.93 & 15.35 & 2.77 & 11.80 & 14.4 \\
\hline 14 & 20 & 13.94 & 4.56 & 6.98 & 12.98 \\
\hline 15 & 20.65 & 14.56 & 5.91 & 12.96 & 12.53 \\
\hline 16 & 7.93 & 11.47 & 3.15 & 3.67 & 12.66 \\
\hline 17 & 2 & 11.61 & 4.44 & 31.55 & 13.54 \\
\hline 18 & 2 & 13.12 & 5.39 & 20.04 & 13.6 \\
\hline 19 & 2 & 16.56 & 2 & 10.97 & 15.69 \\
\hline 20 & 7.96 & 15 & 3 & 7.71 & 13 \\
\hline 21 & 20.34 & 13 & 3.19 & 21.97 & 18.31 \\
\hline 22 & 14.28 & 13.32 & 4.19 & 9.87 & 15.88 \\
\hline 23 & 9 & 13.1 & 3 & 8.81 & 15 \\
\hline 24 & 6 & 13.5 & 2 & 6.31 & 12.7 \\
\hline 25 & 13.3 & 13.3 & 3.3 & 7 & 12.03 \\
\hline 26 & 6 & 13 & 2 & 5.7 & 12.9 \\
\hline 27 & 17.1 & 13.11 & 3.1 & 6 & 13 \\
\hline 28 & 11 & 16.1 & 1.91 & 13.51 & 13.53 \\
\hline 29 & 6 & 12.8 & 2 & 5.9 & 12 \\
\hline 30 & 13 & 13.3 & 3.31 & 5.7 & 13.9 \\
\hline
\end{tabular}


TABLE 5. The traffic volume of pedestrians at the traffic count station No 2 - area of Al-Hussein - Al-Fayha bridge at rush hour

\begin{tabular}{|c|c|c|c|}
\hline $\begin{array}{c}\text { Orientation: from the garage to the city center } \\
\text { Babel District }\end{array}$ & $\begin{array}{c}\text { Orientation: from the city center Babel District to } \\
\text { the internal transport garage }\end{array}$ \\
\hline $\begin{array}{c}\text { Traffic volume } \\
\text { of pedestrians }\end{array}$ & $\begin{array}{c}\text { Time } \\
{[\mathrm{min}]}\end{array}$ & $\begin{array}{c}\text { Traffic volume } \\
\text { of pedestrians }\end{array}$ & $\begin{array}{c}\text { Time } \\
{[\mathrm{min}]}\end{array}$ \\
\hline 89 & $0-5$ & 49 & $0-5$ \\
\hline 82 & $5-10$ & 60 & $5-10$ \\
\hline 97 & $10-15$ & 49 & $10-15$ \\
\hline 112 & $15-20$ & 51 & $15-20$ \\
\hline 69 & $20-25$ & 56 & $20-25$ \\
\hline 86 & $25-30$ & 63 & $25-30$ \\
\hline 88 & $30-35$ & 69 & $30-35$ \\
\hline 82 & $35-40$ & 71 & $35-40$ \\
\hline 102 & $40-45$ & 49 & $40-45$ \\
\hline 80 & $45-50$ & 33 & $45-50$ \\
\hline 75 & $50-55$ & 45 & $50-55$ \\
\hline 80 & $55-60$ & 38 & $55-60$ \\
\hline
\end{tabular}

TABLE 6. The time taken for the crossing of pedestrians using the road to the traffic count station No 3 - area of $60^{\text {th }}$ Street - the bridge crossing near the Academy of Fine Arts

\begin{tabular}{|c|c|c|c|c|c|}
\hline No & $\begin{array}{c}\text { Standby time } \\
\text { before transit } \\
{[\mathrm{s}]}\end{array}$ & $\begin{array}{c}\text { Time of } \\
\text { crossing street } \\
{[\mathrm{s}]}\end{array}$ & $\begin{array}{c}\text { Time to walk } \\
\text { on the middle } \\
\text { carrot } \\
{[\mathrm{s}]}\end{array}$ & $\begin{array}{c}\text { Wait time } \\
\text { on the carrot } \\
{[\mathrm{s}]}\end{array}$ & $\begin{array}{c}\text { Transit time } \\
\text { of the other } \\
\text { direction } \\
{[\mathrm{s}]}\end{array}$ \\
\hline 1 & 29 & 17.5 & 15.51 & 10 & 16.9 \\
\hline 2 & 18 & 14.72 & 8.83 & 5 & 16 \\
\hline 3 & 15 & 15.85 & 10.33 & 3 & 15.44 \\
\hline 4 & 21 & 16 & 12.83 & 16.32 & 17.39 \\
\hline 5 & 20 & 13 & 7 & 75 & 15.4 \\
\hline 6 & 13 & 13 & 6.55 & 10.78 & 16 \\
\hline 7 & 11 & 17 & 10.65 & 2 & 17 \\
\hline 8 & 6 & 15 & 5 & 41.15 & 13.87 \\
\hline 9 & 17 & 16.91 & 5.44 & 35.71 & 17.73 \\
\hline 10 & 24.21 & 13 & 7 & 14 & 14 \\
\hline 11 & 11 & 15 & 6.19 & 9.13 & 15.04 \\
\hline 12 & 13.95 & 16 & 7.30 & 6.7 & 14 \\
\hline 13 & 7.3 & 15.83 & 9.30 & 2 & 16 \\
\hline 14 & 29.54 & 13.69 & 4 & 5 & 14.2 \\
\hline 15 & 9 & 14.7 & 4 & 10.81 & 17.79 \\
\hline
\end{tabular}


TABLE 6 cont.

\begin{tabular}{|c|c|c|c|c|c|}
\hline No & $\begin{array}{c}\text { Standby time } \\
\text { before transit } \\
{[\mathrm{s}]}\end{array}$ & $\begin{array}{c}\text { Time of } \\
\text { crossing street } \\
{[\mathrm{s}]}\end{array}$ & $\begin{array}{c}\text { Time to walk } \\
\text { on the middle } \\
\text { carrot } \\
{[\mathrm{s}]}\end{array}$ & $\begin{array}{c}\text { Wait time } \\
\text { on the carrot } \\
{[\mathrm{s}]}\end{array}$ & $\begin{array}{c}\text { Transit time } \\
\text { of the other } \\
\text { direction } \\
{[\mathrm{s}]}\end{array}$ \\
\hline 16 & 6 & 13.56 & 4.9 & 2 & 14.5 \\
\hline 17 & 17 & 16 & 5.4 & 23.6 & 15.5 \\
\hline 18 & 3 & 15.1 & 3 & 12 & 14.91 \\
\hline 19 & 21 & 15 & 5 & 19.2 & 15 \\
\hline 20 & 23 & 14.7 & 4.3 & 14.6 & 14.2 \\
\hline 21 & 18 & 14.5 & 7 & 15 & 14.6 \\
\hline 22 & 5 & 14.3 & 12.63 & 10 & 15.09 \\
\hline 23 & 13 & 13.9 & 10.5 & 15.2 & 13.89 \\
\hline 24 & 9 & 16.1 & 7.43 & 23.5 & 15.69 \\
\hline 25 & 16 & 14.1 & 4.9 & 5 & 15.2 \\
\hline 26 & 3 & 14.1 & 4 & 9 & 14.9 \\
\hline 27 & 16 & 13.5 & 4.1 & 16 & 14.6 \\
\hline 28 & 9 & 13 & 4.79 & 23.95 & 14.1 \\
\hline 29 & 6 & 14.8 & 7 & 8 & 14.9 \\
\hline 30 & 5 & 15.2 & 7 & 15 & 13.9 \\
\hline
\end{tabular}

TABLE 7. The pedestrian traffic volume at the traffic count station No 3 - area of $60^{\text {th }}$ Street - bridge crossing near the Academy of Fine Arts at rush hour traffic

\begin{tabular}{|c|c|c|c|c|c|}
\hline \multicolumn{2}{|c|}{ Orientation: towards the Academy of Fine Arts } & \multicolumn{3}{|c|}{ Orientation: opposite (Civil Defense) } \\
\hline $\begin{array}{c}\text { Traffic volume } \\
\text { of pedestrians on } \\
\text { the ground }\end{array}$ & $\begin{array}{c}\text { Traffic volume } \\
\text { of pedestrians on } \\
\text { bridge }\end{array}$ & $\begin{array}{c}\text { Time } \\
{[\mathrm{min}]}\end{array}$ & $\begin{array}{c}\text { Traffic volume } \\
\text { of pedestrians on } \\
\text { the ground }\end{array}$ & $\begin{array}{c}\text { Traffic volume } \\
\text { of pedestrians on } \\
\text { bridge }\end{array}$ & $\begin{array}{c}\text { Time } \\
\text { [min] }\end{array}$ \\
\hline 42 & 2 & $0-5$ & 12 & 1 & $0-5$ \\
\hline 51 & - & $5-10$ & 9 & - & $5-10$ \\
\hline 51 & - & $10-15$ & 7 & - & $10-15$ \\
\hline 57 & 1 & $15-20$ & 6 & - & $15-20$ \\
\hline 53 & 1 & $20-25$ & 15 & $-20-25$ \\
\hline 39 & 3 & $25-30$ & 17 & - & $25-30$ \\
\hline 56 & - & $30-35$ & 12 & $-30-35$ \\
\hline 61 & 1 & $35-40$ & 14 & - & $35-40$ \\
\hline 67 & - & $40-45$ & 12 & - & $40-45$ \\
\hline 49 & 1 & $45-50$ & 9 & - & $45-50$ \\
\hline 63 & - & $50-55$ & 8 & $5-55$ \\
\hline 50 & 1 & $55-60$ & 8 & -60 \\
\hline
\end{tabular}


TABLE 8 . The time taken by pedestrians to cross the bridge* and reach the traffic count station No 3 - area of $60^{\text {th }}$ Street - bridge crossing near the Academy of Fine Arts

\begin{tabular}{|c|c|c|c|}
\hline No & $\begin{array}{c}\text { Bridge } \\
\text { rise time } \\
{[\mathrm{s}]}\end{array}$ & $\begin{array}{c}\text { Time } \\
\text { on the bridge } \\
{[\mathrm{s}]}\end{array}$ & $\begin{array}{c}\text { Time } \\
\text { of descent } \\
\text { of bridge } \\
{[\mathrm{s}]}\end{array}$ \\
\hline 1 & 40 & 56 & 38 \\
\hline 2 & 39.2 & 58.5 & 41.2 \\
\hline 3 & 44 & 60.6 & 37.9 \\
\hline 4 & 41 & 53 & 35.38 \\
\hline 5 & 46 & 56 & 41.6 \\
\hline 6 & 51 & 63 & 44.2 \\
\hline 7 & 43 & 52.89 & 39.6 \\
\hline 8 & 39 & 56 & 37 \\
\hline 9 & 48 & 57 & 43 \\
\hline 10 & 47 & 56 & 41 \\
\hline
\end{tabular}

*Pedestrian bridge parameters: number of ascending degrees: 40; number of degrees of descent: 40; height of the ladder: $5.20 \mathrm{~m}$; class width: $30 \mathrm{~cm}$, class height: $16 \mathrm{~cm}$.

TABLE 9. The time taken for the crossing of pedestrians using the road to the traffic count station No $4-$ area of $40^{\text {th }}$ Street

\begin{tabular}{|c|c|c|c|c|c|}
\hline No & $\begin{array}{c}\text { Standby time } \\
\text { before transit } \\
{[\mathrm{s}]}\end{array}$ & $\begin{array}{c}\text { Time of } \\
\text { crossing street } \\
\text { [s] }\end{array}$ & $\begin{array}{l}\text { Time to walk } \\
\text { on the middle } \\
\text { carrot } \\
{[\mathrm{s}]}\end{array}$ & $\begin{array}{c}\text { Wait time } \\
\text { on the carrot } \\
{[\mathrm{s}]}\end{array}$ & $\begin{array}{c}\text { Transit time of } \\
\text { the other } \\
\text { direction } \\
{[\mathrm{s}]}\end{array}$ \\
\hline 1 & 10 & 13 & 9 & 10 & 14 \\
\hline 2 & 11 & 12 & 6 & 12 & 16 \\
\hline 3 & 10 & 13 & 5 & 16 & 19 \\
\hline 4 & 13 & 13 & 5 & 10 & 13 \\
\hline 5 & 5 & 13 & 5 & 10 & 14 \\
\hline 6 & 6 & 15 & 3 & 11 & 15 \\
\hline 7 & 9 & 15 & 5 & 13 & 16 \\
\hline 8 & 3 & 15 & 4 & 14 & 14 \\
\hline 9 & 5 & 15 & 8 & 19 & 15 \\
\hline 10 & 5 & 16 & 7 & 10 & 19 \\
\hline 11 & 11 & 16 & 7 & 8 & 19 \\
\hline 12 & 12 & 17 & 5 & 5 & 19 \\
\hline 13 & 15 & 17 & 5 & 3 & 20 \\
\hline 14 & 15 & 18 & 4 & 4 & 13 \\
\hline 15 & 13 & 19 & 5 & 5 & 13 \\
\hline
\end{tabular}


TABLE 9 cont.

\begin{tabular}{|c|c|c|c|c|c|}
\hline No & $\begin{array}{c}\text { Standby time } \\
\text { before transit } \\
{[\mathrm{s}]}\end{array}$ & $\begin{array}{c}\text { Time of } \\
\text { crossing street } \\
{[\mathrm{s}]}\end{array}$ & $\begin{array}{c}\text { Time to walk } \\
\text { on the middle } \\
\text { carrot } \\
{[\mathrm{s}]}\end{array}$ & $\begin{array}{c}\text { Wait time } \\
\text { on the carrot } \\
{[\mathrm{s}]}\end{array}$ & $\begin{array}{c}\text { Transit time of } \\
\text { the other } \\
\text { direction } \\
{[\mathrm{s}]}\end{array}$ \\
\hline 16 & 12 & 16 & 4 & 6 & 15 \\
\hline 17 & 10 & 15 & 4 & 7 & 15 \\
\hline 18 & 10 & 14 & 3 & 7 & 13 \\
\hline 19 & 7 & 14 & 4 & 10 & 12 \\
\hline 20 & 5 & 13 & 5 & 17 & 14 \\
\hline 21 & 7 & 14 & 5 & 19 & 14 \\
\hline 22 & 7 & 16 & 5 & 17 & 16 \\
\hline 23 & 5 & 17 & 8 & 10 & 16 \\
\hline 24 & 5 & 14 & 8 & 11 & 15 \\
\hline 25 & 9 & 15 & 7 & 13 & 15 \\
\hline 26 & 8 & 15 & 5 & 10 & 16 \\
\hline 27 & 9 & 14 & 6 & 11 & 17 \\
\hline 28 & 9 & 12 & 7 & 13 & 14 \\
\hline 29 & 5 & 11 & 8 & 12 & 14 \\
\hline 30 & 9 & 13 & 7 & 11 & 15 \\
\hline
\end{tabular}

TABLE 10. The traffic volume of pedestrians at the traffic count station No $4-$ area of $40^{\text {th }}$ Street at rush hour

\begin{tabular}{|c|c|c|c|}
\hline Orientation: toward the Endowments Department & \multicolumn{2}{|c|}{ Orientation: towards the shops } \\
\hline $\begin{array}{c}\text { Traffic volume } \\
\text { of pedestrians }\end{array}$ & $\begin{array}{c}\text { Time } \\
{[\mathrm{min}]}\end{array}$ & $\begin{array}{c}\text { Traffic volume } \\
\text { of pedestrians }\end{array}$ & $\begin{array}{c}\text { Time } \\
{[\mathrm{min}]}\end{array}$ \\
\hline 13 & $0-5$ & 25 & $0-5$ \\
\hline 15 & $5-10$ & 15 & $5-10$ \\
\hline 6 & $10-15$ & 18 & $10-15$ \\
\hline 9 & $15-20$ & 22 & $15-20$ \\
\hline 11 & $20-25$ & 30 & $20-25$ \\
\hline 9 & $25-30$ & 25 & $25-30$ \\
\hline 8 & $30-35$ & 25 & $30-35$ \\
\hline 10 & $35-40$ & 27 & $35-40$ \\
\hline 10 & $40-45$ & 29 & $40-45$ \\
\hline 12 & $45-50$ & 33 & $45-50$ \\
\hline 3 & $50-55$ & 30 & $50-55$ \\
\hline 5 & $55-60$ & 22 & $55-60$ \\
\hline
\end{tabular}


TABLE 11. The sample of the survey* of the corresponding pedestrian

\begin{tabular}{|l|c|c|c|c|c|c|}
\hline \multirow{2}{*}{ Specification } & \multicolumn{7}{|c|}{ Sample } \\
\cline { 2 - 8 } & 1 & 2 & 3 & 4 & 5 & 6 \\
\hline 1. Age & 28 & 55 & 19 & 18 & 27 & 21 \\
\hline 2. Gender & female & male & male & female & male & male \\
\hline 3. Occupation & employee & other & student & student & other & student \\
\hline $\begin{array}{l}\text { 4. How did you get to this area } \\
\text { (car/walk)? }\end{array}$ & walk & car & car & car & car & car \\
\hline $\begin{array}{l}\text { 5. Why not use the bridge? } \\
\text { a) lack of time } \\
\text { b) rest } \\
\text { c) not to use the electric ladder } \\
\text { d) other }\end{array}$ & a & b & c & b & a & a \\
\hline $\begin{array}{l}\text { 6. Why use the bridge? } \\
\text { a) safety } \\
\text { b) availability of time } \\
\text { c) rest } \\
\text { d) other }\end{array}$ & a & a & a & a & d & a \\
\hline $\begin{array}{l}\text { 7. Do you consider land transit } \\
\text { a violation? }\end{array}$ & yes & no & no & no & yes & yes \\
\hline $\begin{array}{l}\text { 8. If a fine was imposed, will } \\
\text { the bridge be used? }\end{array}$ & yes & yes & yes & yes & yes & yes \\
\hline
\end{tabular}

*Survey was conducted at the traffic count station No 3, $60^{\text {th }}$ Street, on 2 March 2018 (Monday) at $7: 45-8: 45$. Weather that day was described as partly cloudy.

everyone stressed it is understandable that if a fine is imposed, the bridge will be used. Figures 6, 7, 8 and 9 show the time and transit conditions of the field data.

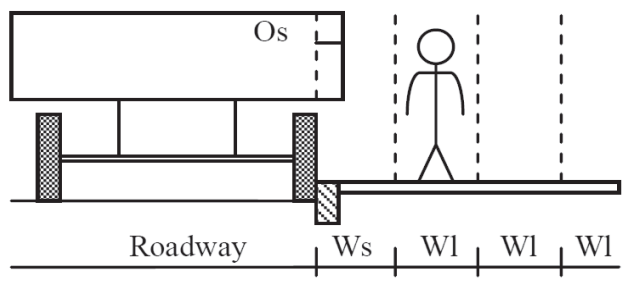

FIGURE 6. The safety and safety requirements require that the side walkways: $W_{S}$ - width of safety strip; $W_{l}-$ width of the pedestrian traffic lane; $O_{s}-$ side overhand

\section{Principles and criteria adopted}

According to the recommendations of AASHTO (AASHTO, 2001; Mok, Landphair \& Naderi, 2006) the safety and safety requirements demand that the side walkways of the pedestrian crossing be as follows: width of safety strip of $0.5 \mathrm{~m}$; width of the pedestrian traffic lane of $0.75 \mathrm{~m}$ (Fig. 6). Thus, the width of the first pedestrian walkway $\left(W_{s}+W_{l}=1.5\right.$ $\mathrm{m})$ was not observed in some areas of the study area.

Under the recommendations of AASHTO and the specifications of the General Authority for Iraqi Roads and Bridges, the volumes traffic for pedestrians and traffic speed as in Table 12. 
TABLE 12. Traffic for pedestrians and traffic speed

\begin{tabular}{|c|c|c|c|c|c|c|c|}
\hline Road section & \multicolumn{7}{|c|}{ Specification } \\
\hline & \multicolumn{7}{|c|}{ Design speed of road $\left[\mathrm{km} \cdot \mathrm{h}^{-1}\right]$} \\
\hline Rural and suburban & 80 & 70 & 60 & 50 & 40 & 30 & 15 \\
\hline \multicolumn{8}{|c|}{ Pedestrian volume per hour } \\
\hline Rural and suburban & 189 & 218 & 257 & 313 & 400 & 553 & 900 \\
\hline Vicinity and bus stations & 9 & 11 & 13 & 16 & 20 & 28 & 65 \\
\hline
\end{tabular}

The speed of traffic at the traffic count station No 3 is $60\left(80 \mathrm{~km} \cdot \mathrm{h}^{-1}\right)$ and pedestrian traffic is higher than 189 pedestrian per hour.

The technical specifications of the General Authority for Iraqi Roads and Bridges for the pedestrian crossing bridges are as follows: width of 28-32 $\mathrm{cm}$; height of 14-16 cm; change the level: each $1.5-1.8 \mathrm{~m}$.

It has been observed that the pedestrian crossing bridge on $60^{\text {th }}$ Street is not in accordance with the specifications in terms of change in the level, since in this bridge is $2.2 \mathrm{~m}$. This leads to the inconvenience of the bridge for the pedestrians from the stress and the suffering of pedestrians, especially in the case of boarding, which negatively affected the use of the bridge to cross by pedestrians.

\section{Conclusions and recommendations}

1. Pedestrian crossing in all the stations of the study area is random and unorganized crossing and the most dangerous in this transit is a sudden crossing. The study area has been unable to provide safe havens for pedestrians by planning or placing signs, signs and traffic signs that provide the pedestrian with the right to pass.
2. The poor sidewalks and the neglect of maintenance requirements and the frequent excesses in the area of Babel District made pedestrians use the river road and thus exposed to the risks of traffic volumes of vehicles.

3. The side walkway of Al-Fayha bridge on the left is not identical to the technical specifications mentioned in terms of width and therefore in terms of the size of the pedestrian traffic. The width of the current walkway $(0.5 \mathrm{~m})$ should be implement in a special width $(1.5 \mathrm{~m})$ for pedestrians, which calls on other pedestrians to follow the path of the road and exposure to multiple dangers.

4. There is a need to design an extension of the island in the intersection of Al-Fayha bridge with the road leading to the internal transport garage. Built extension will reduce the design speed on the bridge, so pedestrians will use this the carrot in the path is bound not to walk in the river road as it is now.

5. That the waiting time in transit in all areas of study is very high and thus increase the time of delay in the journey (pedestrian delay) and based on the divergence pedestrian behavior, the lack of patience of some of them may expose them to break the road 
incorrectly, which puts them in danger as stated in paragraph above.

6. Pedestrian bridges are not identical on $60^{\text {th }}$ Street in terms of landing where changes are required (each 1.5-1.8 m), while the stairs are carried up (2.25-2.50 m).

7. This increases the effort and effort to climb the stairs and as a result leads to the reluctance of pedestrians to use.

8. The allocation of financial and human resources to conduct a comprehensive study of pedestrians in the city of Hilla, and in coordination with the relevant departments, including the situation of pedestrians and their environment with the study of the need for transit facilities and side walkways and provide safe spaces to move them along with studying the time of trips and distance of walking due to the importance of this issue and the lack of the city to such studies with study walking distance for pedestrians where more than $20 \mathrm{~min}$ are allocated to areas of the pedestrian assembly and then transferred to their destinations.

9. The use of international standards and general technical specifications for roads and bridges for the development of tracks or walkways taking into account the land uses and future growth of traffic and pedestrians and to prepare these designs by specialized advisory offices are not subject to discretion.

10. Furnishing roads and intersections in the city of Hilla with signs and traffic signals warning and guidance with planning in the transit areas and selecting them scientifically and studied, which will ensure the smooth and safe in the crossing of pedestrians.

\section{References}

American Association of State Highway and Transportation Officials [AASHTO] (2001). A Policy on Geometric Design of Highway and Streets. Washington: AASHTO.

Batty, M., Axhausen, K.W., Giannotti, F., Pozdnoukhov, A., Bazzani, A., Wachowicz, M. \& Portugali, Y. (2012). Smart cities of the future. The European Physical Journal Special Topics, 214(1), 481-518.

Brand, S. (2010). Whole Earth Discipline: Why Dense Cities, Nuclear Power, Transgenic Crops, Restored Wildlands, and Geoengineering Are Necessary. New York: Penguin Group.

Garber, N.J. \& Hoel, L.A. (2002). Traffic \& Highway Engineering. Toronto: Thomson Learning.

Iraqi Ministry of Highway and Construction (1982). Highway design manual. Baghdad: Ministry of Highway and Construction.

Iraqi Ministry of Interior (1984). Baghdad comprehensive transportation study. Final Report. Baghdad: Scott Wilson Kink Patrick and Partners.

Mok, J.H., Landphair, H.C. \& Naderi, J.R. (2006). Landscape improvement affects roadside safety in Texas. Landscape and Urban Planning, 78(3), 263-274.

Owira, O.I. (2009). Integrating non-motorized transport into the urban transport system - a study of Westlands Commercial Centre (doctoral dissertation). Nairobi: University of Nairobi.

\section{Summary}

Studying and evaluating the performance of pedestrian crossing facilities in $\mathrm{Ba}-$ bil governorate. Walking is one of the oldest means of mobility. It is an indispensable necessity to reach destinations despite the fact 
that walking or walking is one of everyday activities of man, which have positive effects on health, and activity on the one hand; vehicles cannot reach destinations only required by often walking from the other. The main problem address by the research is the random passage of the sieve and uncontrolled when it is most designs for the city's road network have not addressed. This fundamental problem as well as the lack of a city to the safe facilities to cross the pedestrian. Therefore, this paper is a trial to study and analyze the current reality of crossing the sap then find solutions and treatments that reduce or limit the overlap between different traffic events and events crossing the pedestrian. Field data on the syllabic traffic volumes collected in all areas of the study (peak hour volume) and the photographic technique method. The study chose four areas to study the sap $\left(60^{\text {th }}\right.$ Street, $40^{\text {th }}$ Street, Al-Hussein, intersection circle at Babel Health Department), which are residential, commercial and educational zones, representing diversity in land use and scheme sidewalk and the design of the city of Hilla. The study attempted to show the state of lateral walks. The study also used the questionnaire method (interview survey) to determine the suitability of pedestrian bridges in transit and land transit.
The study concluded that the area of Al-Hussein represents the highest traffic volumes of the sieve in addition to the lack of it the sidewalks in terms of absorption and quality and abuses. As well as the reluctance to use pedestrian bridges in transit in the area of $60^{\text {th }}$ Street through high ground transit time, which necessitates the establishment of dual-step (fixed and mobile) - legislation and education through all means.

\section{Authors' address:}

Ali Jaafar Dakhil

(https://orcid.org/0000-0002-3598-261X)

Saba Mohammad Shaheed

University of Al-Qadisiyah

Collage of Engineering

Department of Road and Transport Engineering University of Al-Qadisiyah, 58002, Diwaniya

Iraq

e-mail: ali.jaafar@qu.edu.iq; almohandesali81g@gmail.com Saba.shaheed@qu.edu.iq

Dheyaa A. Alobaidi

Iraqi Ministry of Education

Al-Qadisiyah

Iraq

e-mail: dheyaa.alobaidi@gmail.com 